\title{
Agricultural encroachment in Uganda's Kibale Forest
}

\author{
Karl G. Van Orsdol
}

During Uganda's political troubles in the 1970s the country's few remaining natural forests suffered acutely from illegal human encroachment, poor management practices and poaching of endangered forest wildlife. While the Kibale Forest suffered from many problems, agricultural encroachment alone destroyed some $97 \mathrm{sq} \mathrm{km}$, or 17 per cent, of the Reserve between 1971 and 1982. In 1983 the Government of Uganda initiated steps to halt the spread of encroachment and to reassert authority over its forest resources.

Following the return to civilian rule in 1981, the Ugandan Government showed renewed interest in its forest resources. Unfortunately, little up-todate information was available. In order to help remedy this, I carried out a survey of the Kibale Forest Reserve between June 1982 and January 1983 on behalf of the Ministry of Agriculture and Forestry, the New York Zoological Society and the African Wildlife Foundation (Van Orsdol, 1983).

\section{The Kibale Forest}

Kibale is a medium-altitude forest in southwestern Uganda. The Reserve consists of approximately $350 \mathrm{sq} \mathrm{km}$ of forest and $210 \mathrm{sq} \mathrm{km}$ of grassland and swamps. Two areas within the Reserve have been declared nature reserves in which all exploitation is prohibited (Figure 1). These areas, of $2 \mathrm{sq} \mathrm{km}$ and $60 \mathrm{sq} \mathrm{km}$, respectively, are designated by current Department policy only, and are not recognized as areas of particular biological importance nor of special legal status. A third area of $12 \mathrm{sq} \mathrm{km}$ has been Agricultural encroachment in Uganda declared a research plot where the Kibale Forest Project is carrying out studies on primate ecology and the effects of timber harvesting on the forest ecosystem. Apart from these three regions, human exploitation of forest resources is a major priority of Forest Department policy.

Approximately $134 \mathrm{sq} \mathrm{km}$ in the south of Kibale is included in the Kibale Forest Corridor Game Reserve. This is jointly administered by the Forest Department in the Ministry of Agriculture and Forestry, and the Game Department in the Ministry of Wildlife and Tourism. The Game Reserve was designed to promote movement of wildlife between the Forest Reserve and Queen Elizabeth (formerly Rwenzori) National Park, which lies $6 \mathrm{~km}$ to the south.

Kibale supports one of the richest arrays of fauna of any East African forest; there are 11 species of primate, including the red colobus Colobus badius, black-and-white colobus $C$. guereza, chimpanzee Pan troglodytes and L'Hoest's monkey Cercopithecus Ihoesti. Kibale is also an important sanctuary for the elephant Loxodonta africana population, which was severely reduced in Uganda by poaching (Malpas, 1980). Because of its proximity to the Congo Forest in Zaire, Kibale contains a number of bird species found nowhere else in East Africa, and supports at least 325 species in 46 families (Skorupa, 1983).

\section{The history of encroachment in Kibale}

The influx of agriculturalists into Kibale began in 1971. Initially, the settlers were Bakiga peoples from extreme south-west Uganda whose increasing population forced them to seek land outside their traditional regions. The local administration 
in Fort Portal allowed them to settle in grassland regions to the west of the Reserve. As these regions became saturated, newly arriving immigrants began settling in the Reserve itself. Without support from the central Government, the Forest Department was unable to control the influx effectively. By 1976 the rate of immigration had increased markedly, and settlement spread deep into the Forest itself as well as into the Game Reserve. This latter trend diminished the effectiveness of the Game Reserve as a corridor between the Forest and National Park, and split the elephant population into two isolated subpopulations. Portions of the Forest and Game Reserves became so densely inhabited that local government established schools, offices and dispensaries. A national census carried out in 1980 indicated that the combined human population within the two reserves exceeded 10,000 inhabitants and could be as high as 17,000.

\section{Survey results}

The results of the national census indicated an alarming amount of encroachment within the Forest Reserve. In order to obtain more detailed information, I carried out a series of foot surveys in various parts of the forest. I interviewed all the people I encountered about their land use practices and land tenure history in the Reserve. The southern extension of the forest, which appeared to have suffered the highest level of encroachment, was selected for the most intensive sampling. These data were compared to data gathered during two aerial surveys of the Reserve: one carried out as part of this study, and another carried out earlier by Dr Robert Malpas on behalf of the World Wildlife Fund.

The results indicated that a maximum of about 320 families (or some 1800 people) actually lived within the forest. As disturbing as these figures were, they were low enough to make a resettlement programme practical.

Unfortunately, human density within grassland regions of the Forest Reserve was found to be in accord with the 1980 census figures. Although time limitations prevented the obtaining of detailed information on grassland settlement, the aerial and ground surveys confirmed that some 7000 people lived in grasslands. While these 116 settlers did not clearcut within the forest, they nevertheless collected firewood and hunted wildlife.

The destruction of forest habitat by encroachment posed a significant problem for the longterm conservation of Kibale. Approximately $97 \mathrm{sq}$ $\mathrm{km}$, or 17 per cent, of the Reserve had been disturbed by encroachment. Of this total, about $42 \mathrm{sq} \mathrm{km}$ consisted of forest habitat and $55 \mathrm{sq} \mathrm{km}$ of grassland habitat (Figure 1). The forest destruction in South Kibale was of particular concern, since it threatened to isolate the main forest block from the National Park. Some $39 \mathrm{sq} \mathrm{km}$ of forest habitat in South Kibale had been felled, leaving only narrow isthmuses of undisturbed forest. In three places, corridors of natural forest had been reduced to less than $1 \mathrm{~km}$ in width, severely hampering the movement of wildlife between South and Central Kibale. The forest had, in effect, been cut into two isolated blocks. Furthermore, throughout southern Kibale, expansion of

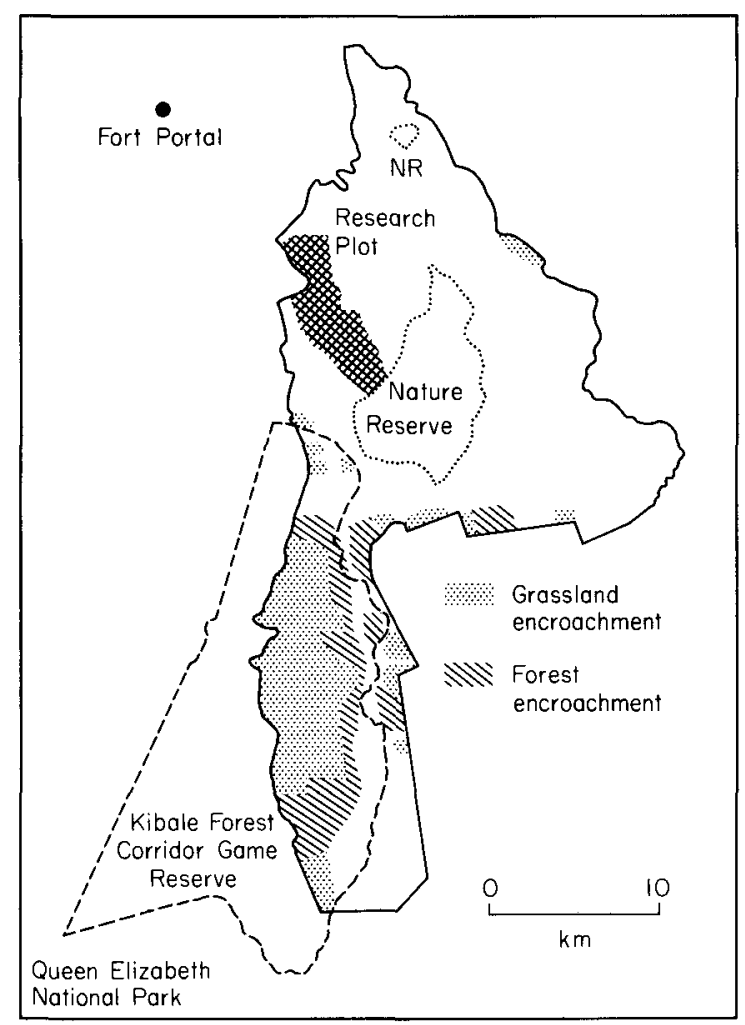

Figure 1. The Kibale Forest Reserve in Western Uganda. Oryx Vol 20 No 2, April 1986 
agriculture continually whittled away at the forest boundary.

The attitude of the forest settlers to their legal status within the Reserve appeared to be indifferent. While over 90 per cent of those interviewed admitted that their presence was illegal, few displayed concern over the potential repercussions. The majority felt that no action would be taken against them, given the inability of the authorities to evict settlers in the past. Over 80 per cent said that they would agree to settlement outside the Reserve should the Government provide alternative land. Resettlement would not be a problem for 12 per cent of forest encroachers and 41 per cent of grassland settlers who admitted to owning land outside the Reserve.

\section{Government action}

In 1983 the Ugandan Government initiated some important first steps in dealing with the problems besetting Kibale Forest. The Minister of Agriculture and Forestry visited Kibale to see the problem first hand, the first such visit by a Minister in 15 years. He visited several encroachment sites and discussed the problem with local officials, the Forest Department and the settlers. Support also came from the Ministry of Tourism and Wildlife, which shares administration of South Kibale. In January 1983, announcements over the Voice of Uganda radio ordered all settlers to vacate the Game Reserve within 60 days.

Public response to these announcements was not encouraging at first, with most settlers adopting a 'wait and see' attitude. Combined patrols by forest guards and the police encouraged evacuation of the Reserve, as did the closing of all schools and offices within the Reserve by the local administration. An offer of alternative land northeast of the Reserve by the local government was accepted by many encroachers. By early 1984, as many as 60 per cent of the forest plots and 30 per cent of the grassland plots had been abandoned.

\section{Conclusions}

While the steps taken by the Government to reassert control over its forest resources are hopeful signs, further progress must be achieved if Kibale's future is to be assured. The entire Agricultural encroachment in Uganda boundary of the Reserve should be resurveyed and marked, especially where the forest abuts human settlement. The Forest Act, which has been essentially untouched since its inception in 1963 , is in need of a complete revision to bring it in line with current economic and ecological realities. With an ever increasing need for fuelwood by the rural population, reafforestation is critical if Uganda is to avoid a fuelwood crisis and prevent the destruction of the remaining forests. Within Kibale, larger areas must be set aside for preservation and protection of the forest habitat and its endangered wildlife.

Fortunately, Uganda is receiving support in achieving these goals for Kibale and other forest tracts. An international aid organization is becoming involved in reafforestation in Uganda, and Kibale may become one of its initial project sites. The Government has also requested assistance from IUCN to develop a National Conservation Strategy. This strategy will provide needed assistance in developing a conservation and utilization programme to protect forest resources. Without continued international aid, the future of Uganda's forest will be in jeopardy.

\section{Acknowledgments}

I would like to thank the Ministry of Agriculture and Forestry, Uganda, for co-operation: the Department of Zoology at Makerere University, Kampala, for local sponsorship; the New York Zoological Society for financial support; the African Wildlife Foundation for use of a vehicle: the Kibale Forest Project for facilities and encouragement; Mr Paul Ssali for piloting the aerial census and Dr Robert Malpas of World Wildlife Fund for making available his data from an aerial survey of Kibale.

\section{References}

FAO and UNEP 1981. Forest Resources in Tropical Africa. FAO. Rome.

Malpas. R. (ed.) 1980. Wildlife in Uganda, 1980. Report to the Ministry of Wildlife and Tourism, Kampala, Uganda.

Skorupa, J. 1983. A bird list of Kibale Forest Reserve. New York Zoological Society. NY.

Van Orsdol, K.G. 1983. The status of Kibale Forest Reserve of western Uganda and recommendations for its conservation and management. A report to the Ministry of Agriculture and Forestry. New York Zoological Society and African Wildlife Foundation.

Karl G. Van Orsdol, Kibale Forest Project, Fort Portal, Uganda.

Present address: Environment and Natural Resources Inc. PO Box 60224, Palo Alto, CA 94306, USA. 